Research article

\title{
Cell-extracellular matrix interactions regulate neural differentiation of human embryonic stem cells
} Wu Ma*1, Tara Tavakolii ${ }^{1}$ Eric Derby ${ }^{1}$, Yevgeniya Serebryakova ${ }^{1}$, Mahendra S Rao ${ }^{2}$ and Mark P Mattson ${ }^{3}$

Address: ${ }^{1}$ Stem Cell Center, Developmental Biology, American Type Culture Collection (ATCC), Manassas, VA, USA, ${ }^{2}$ Stem Cells and Regenerative Medicine (Research), Invitrogen, Carlsbad, CA, USA and ${ }^{3}$ Laboratory of Neurosciences, National Institute on Aging Intramural Research Program, Baltimore, MD, USA

Email:Wu Ma* -wma@atcc.org; Tara Tavakoli - ttavakoli@atcc.org; Eric Derby - ederby@atcc.org; Yevgeniya Serebryakova - jserebryakova@atcc.org; Mahendra S Rao - mahendra.rao@invitrogen.com; Mark P Mattson - mattsonm@grc.nia.nih.gov

* Corresponding author

Published: 22 September 2008

BMC Developmental Biology 2008, 8:90 doi:10.1/86/I47|-2/3X-8-90
Received: 17 April 2008

Accepted: 22 September 2008

This article is available from: http://www.biomedcentral.com/I47I-2/3X/8/90

(C) 2008 Ma et al; licensee BioMed Central Ltd.

This is an Open Access article distributed under the terms of the Creative Commons Attribution License (http://creativecommons.org/licenses/by/2.0), which permits unrestricted use, distribution, and reproduction in any medium, provided the original work is properly cited.

\begin{abstract}
Background: Interactions of cells with the extracellular matrix (ECM) are critical for the establishment and maintenance of stem cell self-renewal and differentiation. However, the ECM is a complex mixture of matrix molecules; little is known about the role of ECM components in human embryonic stem cell (hESC) differentiation into neural progenitors and neurons.

Results: A reproducible protocol was used to generate highly homogenous neural progenitors or a mixed population of neural progenitors and neurons from hESCs. This defined adherent culture system allowed us to examine the effect of ECM molecules on neural differentiation of hESCs. hESC-derived differentiating embryoid bodies were plated on Poly-D-Lysine (PDL), PDL/ fibronectin, PDL/laminin, type I collagen and Matrigel, and cultured in neural differentiation medium. We found that the five substrates instructed neural progenitors followed by neuronal differentiation to differing degrees. Glia did not appear until 4 weeks later. Neural progenitor and neuronal generation and neurite outgrowth were significantly greater on laminin and laminin-rich Matrigel substrates than on other 3 substrates. Laminin stimulated hESC-derived neural progenitor expansion and neurite outgrowth in a dose-dependent manner. The laminin-induced neural progenitor expansion was partially blocked by the antibody against integrin $\alpha 6$ or $\beta \mid$ subunit.

Conclusion: We defined laminin as a key ECM molecule to enhance neural progenitor generation, expansion and differentiation into neurons from hESCs. The cell-laminin interactions involve $\alpha 6 \beta$ I integrin receptors implicating a possible role of laminin/ $\alpha 6 \beta$ I integrin signaling in directed neural differentiation of hESCs. Since laminin acts in concert with other ECM molecules in vivo, evaluating cellular responses to the composition of the ECM is essential to clarify further the role of cellmatrix interactions in neural derivation of hESCs.
\end{abstract}

\section{Background}

Increasing evidence has shown that stem cell development requires a niche - a local microenvironment hous- ing stem cells that regulates their self-renewal and fate in developing tissues or organs [1-5]. The regulatory signals from a niche are provided by niche cells, soluble factors 
and the extracellular matrix (ECM). Despite many studies showing that soluble factors such as FGFs, BMPs and Wnts can regulate stem cell behavior, the role of cell-matrix interactions in stem cell development is poorly understood. The ECM as a major niche element provides not only a scaffold for cellular support, but also an immediate microenvironment that triggers regulatory signals to support stem cell proliferation, migration and fate decision [6-8]. The ECM is a complex mixture of matrix molecules which are typically large glycoproteins, including the fibronectins, collagens, laminins and proteoglycans that assemble into fibrils or other complex macromolecular arrays. Cell adhesion to the ECM transmits extracellular signals to stem cells via integrin receptors which are heterodimeric receptors generated by selective pairing between $18 \alpha$ and $8 \beta$ subunits. The complexity of the extracellular environment is revealed by examination of the special and temporal expression of patterns of ECM components and some of their cell surface receptors in the developing central nervous system (CNS) and the peripheral nervous system. Abundant ECM is present at the time when neural progenitors differentiate, migrate and neuronal axons elongate, but expression of ECM proteins is substantially reduced by the end of development $[9,10]$. The diversity of cell interactions with complex ECM components in the developing CNS challenges us to understand the role of cell-matrix interactions in neural differentiation of stem cells.

The ability of embryonic stem (ES) cells to generate neural cell types in vitro offers a powerful tool to study how the cell-ECM interactions regulate neural stem cell specification and lineage choice. Recent studies on mouse embryonic stem cells (mESCs) showed that ECM signaling influences the developmental fate of pluripotent stem cells, and the temporally restricted cell-ECM interactions direct fate and specification of neural precursors derived from mESCs $[11,12]$. In the present study, we used a reproducible, chemically-defined adherent culture system to direct highly purified neural commitment from human embryonic stem cells (hESCs). The robust neuroectodermal cells in neural rosettes were generated and further differentiated into neural progenitors and neurons; glial cells did not appear until 4 weeks later. This system allowed us to study quantitatively how ECM components affect the neural progenitor generation and migration from hESCs and the neurite outgrowth of developing neurons. Among the 5 substrates tested (poly-D-lysine, fibronectin, laminin, collagen and Matrigel) hESC-derived neural progenitor expansion, migration and differentiation into neurons were significantly greater on laminin and laminin-rich Matrigel than on other substrates. Laminin stimulated hESC-derived neural progenitor expansion, neuronal generation and neurite outgrowth in a dosedependent manner. The laminin-induced neural progeni- tor expansion was partially blocked by antibody against integrin $\alpha 6$ or $\beta 1$ suggesting that laminin/ $\alpha 6 \beta 1$ integrin signaling plays a critical role in the directed neural differentiation of hESCs.

\section{Results \\ Derivation of highly homogenous neural progenitors and neurons from $h E S$ cells}

Human ES cell lines TE03 and TE06 were maintained and passaged weekly on mitomycin C treated mouse CF-1 embryonic fibroblasts. Colonies of hESCs were removed from feeders, triturated and re-plated in low attachment dishes to obtain spontaneously differentiating EBs. Neuroectodermal differentiation was induced in floating EBs in the neural differentiation medium (NDM). We found a marked change in appearance of differentiating EBs during culturing with the NDM. By 10 days of culture in the NDM (or 15 days of differentiation), most EBs exhibited a solid, dark core surrounded by a light band which we called "dark EBs" (Fig. 1A at $0 \mathrm{hr}$ ). However, if continually cultured a few more days in suspension with the NDM, some EBs gradually became transparent capsules which we called "light EBs" (Fig. 1B at 0 hr). Both dark- and light-EBs were plated onto cell culture dishes coated with PDL, PDL/ fibronectin, PDL/laminin, collagen and Matrigel. Neural

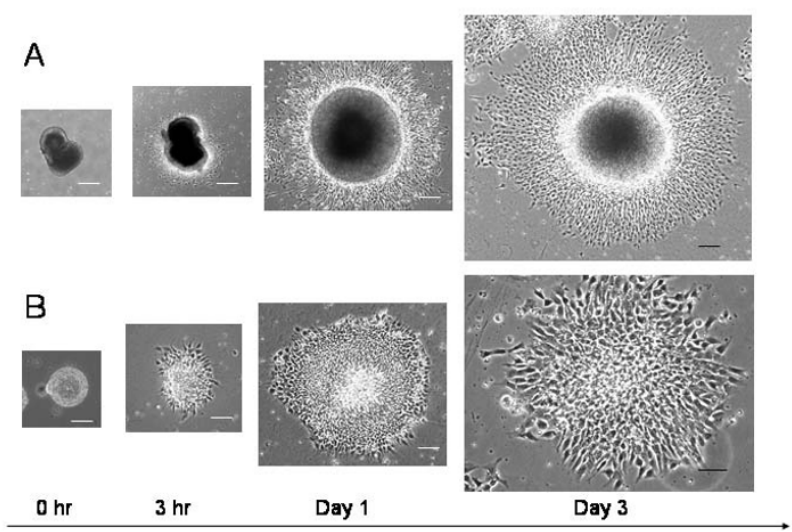

\section{Figure I}

Time-lapse series of two distinct patterns of hESCderived neural differentiation on PDL/Laminin substrates. Phase contrast images of cell expansion at $0 \mathrm{hr}, 3$ hr, I day and 3 days postplating. Some hES cell-derived embryoid bodies (EBs) at I 5 days of differentiation show a solid, dark core (dark EBs) (A at $0 \mathrm{hr}$ postplating) while many EBs at 17-20 days of differentiation exhibit light, transparent appearance (light EBs) (B at $0 \mathrm{hr}$ postplating). (A) From a dark $E B$, new cells constantly generate and radially migrate away from the center of the EB and form a rim of cells. These expanded cells are mixed neural progenitors and neurons (see Fig. 2). (B) light EB gives rise to a homogenous cell population composed of almost all neural progenitors (See Fig. 3). Scale bars: in $(A)=200 \mu \mathrm{m}$; in $(B)=100 \mu \mathrm{m}$. 
rosettes were readily visualized in plated EBs on all substrates except on PDL. Without clonal isolation of neural rosettes, the neuroectodermal cells in the rosettes further differentiated into neural progenitors, neurons and glia on these adherent substrates. After being plated on PDL/laminin substrates, the dark EBs generated the first nestin+ neural progenitors at 3 hours postplating, and the first $\mathrm{Tu} 1+$ neurons appeared 6 hours after the nestin+ neural progenitors generated. From a dark EB, new neural precursors and neurons were constantly generated and migrated radially away from the center of aggregates, resulting in a rim of cells around the EB sphere (Figs. 1A, 2). While the dark EBs gave rise to a mixed population of nestin + neural progenitors and $\mathrm{Tu} 1+$ neurons (Figs. 1A, 2), the light EBs produced highly pure nestin+ progenitors with a few or no TuJ1+ cells (Figs. 1B, 3). In both cases, GFAP+ astrocytes and $\mathrm{O} 4+$ developing oligodendrocytes did not appear until 4 weeks later. Figure 1 shows time-lapse images of these two distinct differentiation patterns from dark EBs and light EBs respectively.

To quantify the percentage of neural progenitors and neurons within hESC-derived differentiated cells, a double immunocytochemical analysis for nestin and TuJ1 was carried out in cultures with nuclear DAPI counterstaining at 3 days postplating on ECM substrates (or 18 days of differentiation). The dark EBs-derived neural cells exhibited a radial configuration; new neural precursors were constantly generated from the dark EB spheres followed by robust neuronal generation. Both neural progenitors and neurons migrated rapidly away from the center of aggregates (Fig. 2). In the mixed neural population the ratio of nestin+ to TuJ1+ cells varied markedly between EBsderived aggregates. By counting the cells positive for nestin or TuJ1 and the number of phase-dark cells positive to DAPI in Figure $2,75 \% \pm 4.2 \%$ of differentiated cells expressed nestin and $24 \% \pm 2.1 \%$ expressed TuJ1. Figure 3 shows a light EBs-derived neural population. Almost all differentiated cells were nestin+ neural progenitors. By counting the cells positive for nestin or TuJ1 over the number of cells positive to DAPI, $98.2 \% \pm 1.4 \%$ of differentiated cells expressed nestin and $1.1 \% \pm 0.4 \%$ expressed TuJ1.

\section{hESC-derived neural rosettes appear on various ECM substrates}

Neuroectodermal precursors in neural rosettes were induced by replating EBs into the NDM. While the markers of undifferentiated hESC such as Oct3/4 and SSEA4 progressively disappeared (not shown), a number of rosettes gradually emerged throughout the EB. Although neural rosettes were seen in floating EBs, more rosettes were generated after the EBs were plated on PDL/laminin (Fig. 4), Matrigel (Fig. 5A-D) and collagen (Fig. 5E-H) substrates, but not on PDL. These radial neuroectodermal cells were morphologically similar to polarized neuroepithelial

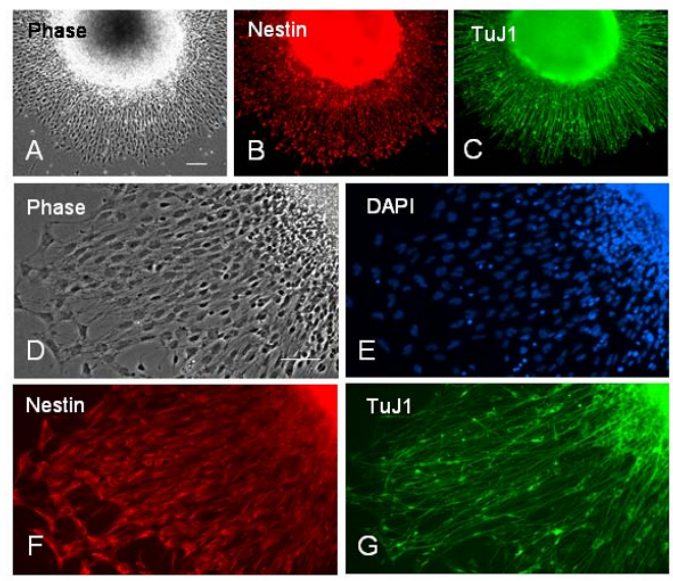

Figure 2

A mixed population of neural progenitors and neurons derived from a dark EB. The dark EB derived from TE03 cell line was plated on PDL/laminin and cultured in the neural differentiation medium (NDM) for 3 days. (A-C) Double-immunostaining of a hESC-defferentiated aggregate for nestin and TuJI. Newly generated nestin+ and TuJI+ cells are migrated radially away from the center of aggregates, forming a rim of neural cells around the EB sphere. (D-G) Higher magnification of differentiated cells in $(A)$ showing a large number of nestin + cells $(F)$ and a few TuJ I+ neurons $(G)$. To estimate the percentage of differentiated cells expressing nestin or TuJ I, the number of labeled cells was counted from a double-immunolabeled culture and normalized with the total number of cells determined by counting DAPI nuclear counterstained cells (E) that overlap phasedark (D) cells. Scale bars: in (A-C) $=200 \mu \mathrm{m}$; in (D-G) 100 $\mu \mathrm{m}$.

structures of the developing CNS. Immunostaining of neuroectodermal cells in rosettes for early neural markers Sox 1 and nestin, and the neuronal marker TuJ1, showed that the radially organized columnar neuroepithelial cells coexpressed Sox 1 and nestin (Fig. 4A, B). Therefore, neural rosettes are considered as in vitro organized neuroectoderm [13-15]. It was interesting to notice that the antibody against neuronal marker TuJ1 not only stained rosette cellderived neurons, but also radially distributed fiber-like structures in rosettes (Fig. 5C, D, G and 5H). About 5-10 days later, the rosettes were often transformed into neural tube like structures (Fig. 4C, D).

\section{hESC-derived neural progenitors are highly proliferative and multipotent}

Our reproducible protocol generated robust hESC-derived neuroectodermal cells giving rise to highly homogenous nestin+ neural progenitors that undergo extensive cell division before differentiating into neuronal and glial cells. To assay the ability of self-renewal of hESC-derived neural progenitors, cells at 18 days of differentiation (or 3 days postplating on laminin substrate) were exposed to BrdU 

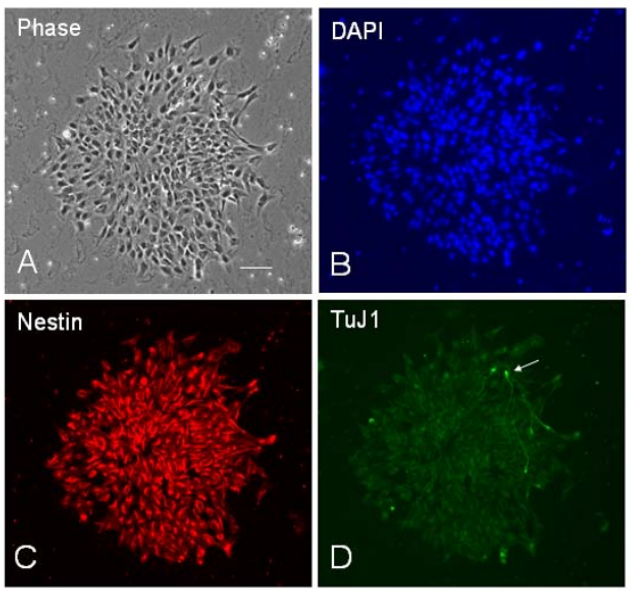

\section{Figure 3}

A homogenous population of nestin+ neural progenitors derived from a light EB. The light EB derived from TE03 cell line was plated on PDL/laminin and cultured in the NDM for 3 days. To estimate the percentage of differentiated cells expressing nestin or TuJ I, the number of labeled cells was counted from a double-immunolabeled culture at 3 days postplating for nestin (C) and TuJ I (D), and normalized with the total number of cells determined by counting DAPI stained cells (B) overlapping phase-dark cells (A). This hESCderived cell population consists of almost all nestin+ progenitors. $T u J I+$ neurons ( $D$, pointed by arrows) are barely seen. Scale bar $=100 \mu \mathrm{m}$.

for 4 hours before double immunostaining for nestin and BrdU. The percentage of nuclei positive for BrdU among the nestin-positive cell population was about 68\% (Fig. $6 \mathrm{~A}-\mathrm{C}$ ), indicating that hESC-derived neural progenitors were actively synthesizing DNA. To characterize the extent to which rosette cells can differentiate into all three neural cell lineages, we used immunocytochemical analysis of cells cultured on PDL/laminin substrates with a panel of antibodies and demonstrated that hESC-derived neural derivatives sequentially expressed Sox1, nestin, musashi (not shown), A2B5 and PS-NCAM, followed by TuJ1 expression in many cells in first 1-5 days postplating on PDL/laminin substrates. MAP2+ and GABAergic $\left(\mathrm{GAD}_{65,67}+\right)$ neurons appeared at about $10-15$ days on PDL/laminin substrates. GFAP+ astrocytes and O4+ developing oligodendrocytes did not appear until after 30 days of culture on PDL/laminin substrates (Fig. 6).

\section{Neural progenitor expansion and differentiation into neurons are significantly greater on laminin or laminin-rich Matrigel}

To examine the effect of substrates on the overall growth (expansion) of neural progenitors derived from dark EBs, similar sized (diameter) EBs with equal number of neural progenitors were chosen at $3 \mathrm{~h}$ postplating. The number of nestin+ cells grown on different substrates was quantified

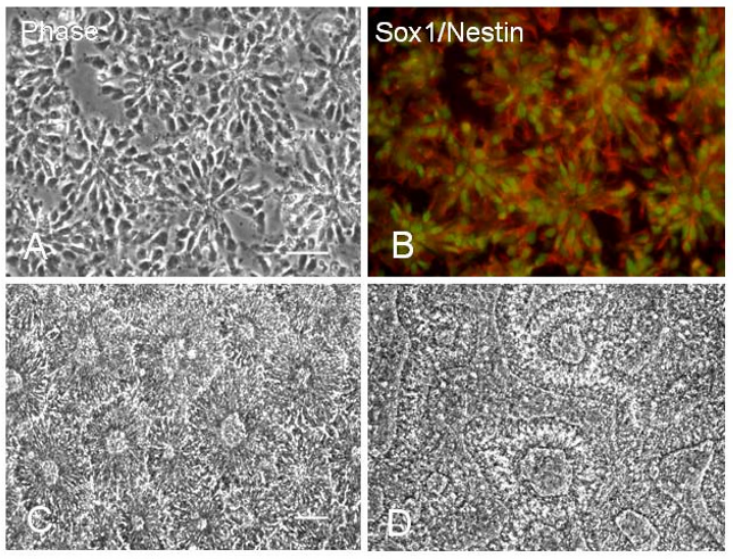

\section{Figure 4}

Human ESC-derived neuroectodermal precursors in neural rosettes (A-B) and neural tube-like structures (C-D). The neural rosettes and neural tube-like structures are found in TE-06-derived EBs cultured on PDL/laminin substrates. Neural rosettes are radial arrangements of columnar cells (A) that co-express Soxl (green) and nestin (red) (B). (C-D) In sister cultures continually fed with NDM for another 3 days, the neural tube-like structures appear. Scale bars: in $(A-B)=50 \mu \mathrm{m}$; in $(C-D)=100 \mu \mathrm{m}$.

over time at $3 \mathrm{~h}, 6 \mathrm{~h}, 12 \mathrm{~h}, 18 \mathrm{~h}, 24 \mathrm{~h}, 36 \mathrm{~h}$ and $48 \mathrm{~h}$ postplating from randomly selected fields. A comparison of cell counts at these 7 time points showed significantly greater cell expansion on PDL/laminin or Matrigel at 12$48 \mathrm{~h}$ postplating than on other substrates (Fig. 7A). At 48 $\mathrm{h}$ postplating, the nestin+ cell number increased on PDL/ laminin by approximately 4 -fold and on Matrigel by about 3 -fold. A comparison of TuJ1+ cells grown on these 5 substrates also indicated that laminin and Matrigel stimulated significantly higher numbers of hESC-derived neurons compared to the other substrates (Fig. 7B).

\section{Neurite outgrowth of hESC-derived neurons is greater on laminin and laminin-rich matrigel}

To evaluate the effect of substrates on the neurite outgrowth of hESC-derived neurons, quantification of the number of primary neurites and total neurite length per cell was carried out on neurons derived from the light EBs. The hESC-derived neurons were identified using immunocytochemistry with the antibody against TuJ1 (Fig. 8A). hESC-derived neurons on laminin and Matrigel had significantly greater numbers of neurites and total neurite length per cell than neurons on other substrates (Fig. 8B, C). The total neurite length per cell on laminin slightly greater than on matrigel, but this difference was not statistically significant (total neurite length per cell \pm SEM: laminin $85 \pm 5.8$, Matrigel $81 \pm 3.8 ; \mathrm{P} \geq 0.1$ for both comparisons). Therefore, laminin-supported neurite outgrowth was comparable to Matrigel. 

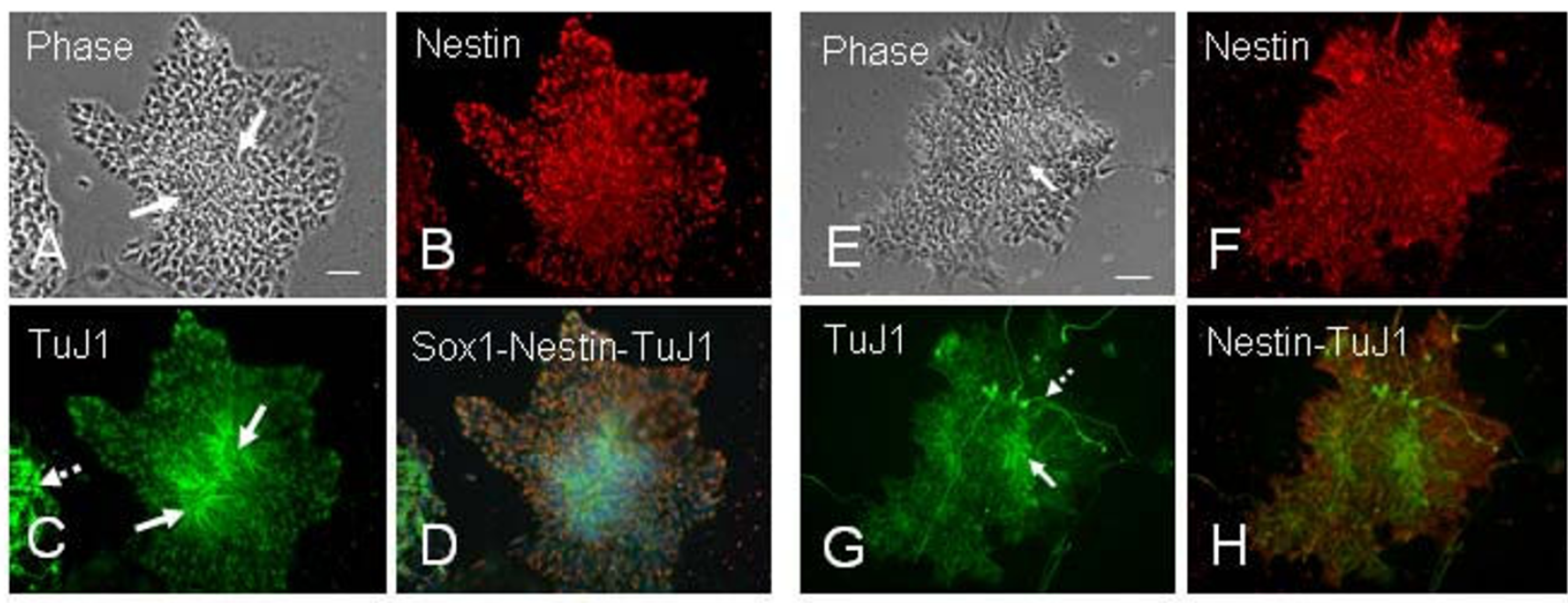

Figure 5

Neural rosettes generated on collagen (A-D) and matrigel (E-H) substrates. (A-D) A TE03-derived light EB at 3 days postplating on type I collagen substrates was triple-immunostained for nestin (B), TuJ I (C) and Sox I (blue in D). Note that TuJ I stains radial configurations of structures in rosettes (pointed by two solid arrows) and a cluster of neurons (pointed by a dished arrow) in (C). Scale bar: $100 \mu \mathrm{m}$. (E-H) Neural rosettes, neural progenitors and neurons are developed in a TE03derived light EB cultured on matrigel for 2 days. A solid arrow in (E) points to a TuJ I-labeld radial arrangement (G) which overlaps a rosette in phase contrast image $(E)$. The dashed arrow in $(G)$ indicates TuJI+ neurons with long processes. The majority of cells in the EB are nestin+ $(F)$. Scale bars in $(A)$ and $(E)=100 \mu \mathrm{m}$.

\section{Laminin stimulates neural progenitor expansion and neurite outgrowth in a dose-dependent manner}

Results from above show that laminin is a particularly effective ECM substrate for stimulating hESC-derived neural progenitor expansion and neuronal neurite outgrowth. To examine a possible dose-dependent relationship between laminin concentrations and hESC-derived neurogenesis, we evaluated the hESC-derived neural progenitor expansion and total neurite length of neurons on culture dishes coated with PDL/laminin substrates. Laminin was used at the following 5 concentrations: $1 \mu \mathrm{g} / \mathrm{ml}(0.25 \mu \mathrm{g} /$ $\left.\mathrm{cm}^{2}\right), 10 \mu \mathrm{g} / \mathrm{ml}\left(2.5 \mu \mathrm{g} / \mathrm{cm}^{2}\right), 30 \mu \mathrm{g} / \mathrm{ml}\left(7.5 \mu \mathrm{g} / \mathrm{cm}^{2}\right), 60$ $\mu \mathrm{g} / \mathrm{ml}\left(15 \mu \mathrm{g} / \mathrm{cm}^{2}\right)$ and $100 \mu \mathrm{g} / \mathrm{ml}\left(25 \mu \mathrm{g} / \mathrm{cm}^{2}\right)$. We observed that both neural progenitor expansion and total neurite length increased in response to increased laminin concentrations from $1 \mu \mathrm{g} / \mathrm{ml}$ to $60 \mu \mathrm{g} / \mathrm{ml}$. The cell expansion and neurite outgrowth declined at higher laminin concentration $(100 \mu \mathrm{g} / \mathrm{ml})$ (Fig. 9A, B).

\section{Distributions of integrins $\alpha \mathrm{I}, \alpha \mathbf{3}, \alpha \mathbf{6}, \beta \mathrm{I}$ and $\beta 4$ in hESC- derived neural progenitors}

Integrins comprise a large family of cell adhesion molecules that mediate interactions between the extracellular environment and the cytoplasm. Since hESC-derived neural progenitors were predominantly interacting with laminin, we examined if the neural progenitors express the laminin-associated integrin subunits. It is known that integrin $\beta 1$ is widely expressed in human postnatal cortices-derived neural progenitor cells [16]. It forms noncova- lent complexes with various integrin alpha subunits, including $\alpha 1, \alpha 3, \alpha 6$, to become the functional receptors that bind specifically to laminin. Flow cytometry showed that the human neural progenitor cells express the laminin-associated integrins $\alpha 1, \alpha 3, \alpha 6, \beta 1$ and $\beta 4$ [16]. We carried out immunostaining of hESC-derived neural progenitors at 3 days postplating on PDL/laminin for integrins $\alpha 1, \alpha 3, \alpha 6, \beta 1$ and $\beta 4$. All these integrin subunits were detectable to differing degrees. Cell counting of immunoreacted vs total number of cells revealed that $98 \%$ $\pm 1.5 \%$ cells expressed $\beta 1$ subunit and $46 \% \pm 8 \%$ cells expressed $\alpha 6$ subunit. There were $38 \% \pm 4 \% \alpha 3$ positive cells, $12 \% \pm 3 \% \alpha 1$ positive cells, and $15 \% \pm 3 \% \beta 4$ positive cells found in hESC-derived neural progenitors.

\section{Blockage of $\alpha 6$ or $\beta$ I integrin disrupts expansion of hESC- derived neural progenitors on laminin substrates}

Results above demonstrated that, compared with other substrates, hESC-derived neural progenitors showed strongest responses to laminin substrates in their migration, expansion and differentiation into neurons. Recent studies have shown that almost all human neural stem and progenitor cells express the $\beta 1$ integrin subunit and a significant percentage of human neural progenitors express a6 subunit [16]. To assess the role of endogenous a 6 and $\beta 1$ integrins in hESC-derived neural progenitor migration and expansion on PDL/laminin substrates, antibody perturbation experiments were performed in dark EBs-derived neural populations cultured at $24 \mathrm{~h}$ postplating. We 

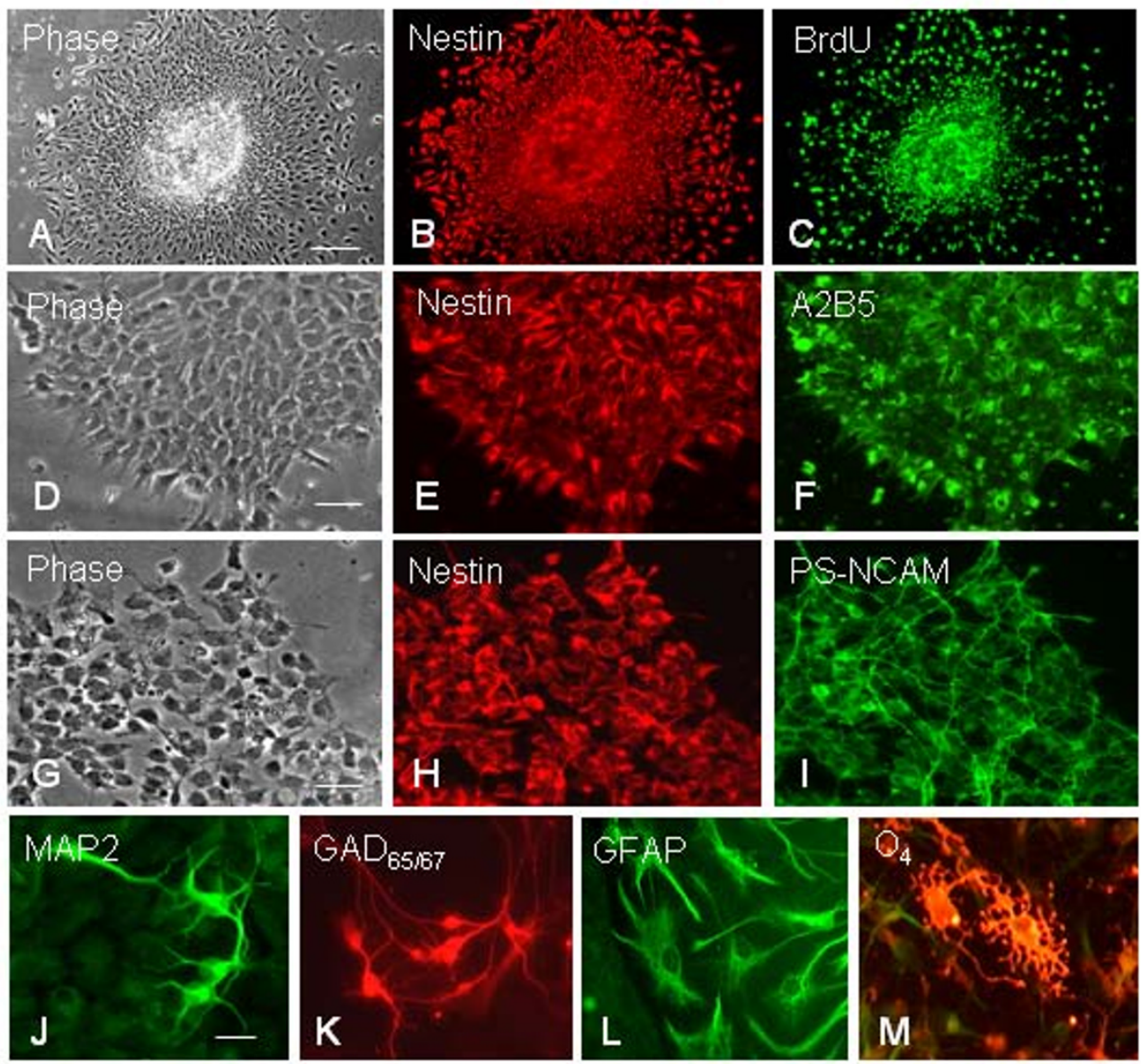

\section{Figure 6}

hESC-derived neural progenitors are highly proliferative and multipotent. (A-C) Double-immunostaining of differentiated cells at 2 days postplating for nestin (red) and proliferative marker BrdU (greed), indicating approximately 68\% of nestin+ cells are BrdU incorporated. (D-F) Double-immunostaining for nestin (red) and A2B5 (green). (G-I) Double-

immunostaining for nestin (red) and PS-NCAM (green). The overlapping of nestin and A2B5 or PS-NCAM indicates that hESCderived nestin + neural progenitors also express other neural differentiating markers. (J-M) Immunostaining of progeny of hESC-derived neural progenitors for mature neuronal marker MAP2 (J), GABAergic neuronal marker $\mathrm{GAD}_{65 / 67}(\mathrm{~K})$, astrocytic marker GFAP (L) and O4, developing oligodentrocyte marker (M). Scale bars: $(A)=200 \mu \mathrm{m} ;(D)=100 \mu \mathrm{m} ;(\mathrm{G})=100 \mu \mathrm{m} ;(\mathrm{J}$ M) $=30 \mu \mathrm{m}$.

marked the similar sized (diameter) dark EBs at the day of plating (or at 15 days after differentiation) in total 12 cell culture dishes coated with PDL/laminin at concentration of $60 \mu \mathrm{g} / \mathrm{ml}$. These dishes were divided into 4 groups: no treatment (Fig. 10A), treated with the antibody against a6 integrin (Fig. 10B), treated with the antibody against $\beta 1$ integrin (Fig. 10C) and treated with purified mouse IgG (Fig. 10D). Cell expansions were estimated at $24 \mathrm{~h}$ postplating by measuring expansion distances from the edge of the EB sphere to the widest point of the rim (Fig. 10A-D). It was found that hESC-derived neural progenitors treated with a6 or $\beta 1$ integrin antibody exhibited significant decreases in cell expansion distances (expansion distance \pm SEM: a6 treated $256 \pm 26 \mu \mathrm{m} ; \beta 1$ treated $301 \pm 32 \mu \mathrm{m}$ ) compared to non-treated cells $(589 \pm 71 \mu \mathrm{m})$ or cells treated with mouse IgG $(574 \pm 65 \mu \mathrm{m})$. Cells untreated or treated with mouse IgG showed no significant difference in cell expansion, whereas statistical differences between $\mathrm{a} 6$ or $\beta 1$ integrin antibody-treated cells and values for control cultures were found significant $\left({ }^{* *} \mathrm{p}<0.01\right)$. This result indicates that a6 31 integrin mediated, at least in part, hESC-derived neural progenitor responses to laminin, suggesting a critical role for laminin/a 6 or $\beta 1$ integrin signaling in hESC-derived neural progenitor cell migration and expansion.

\section{Discussion}

Our work demonstrates that laminin and laminin-rich Matrigel significantly enhanced directed hESC differentiation into neural progenitors and neurons compared 


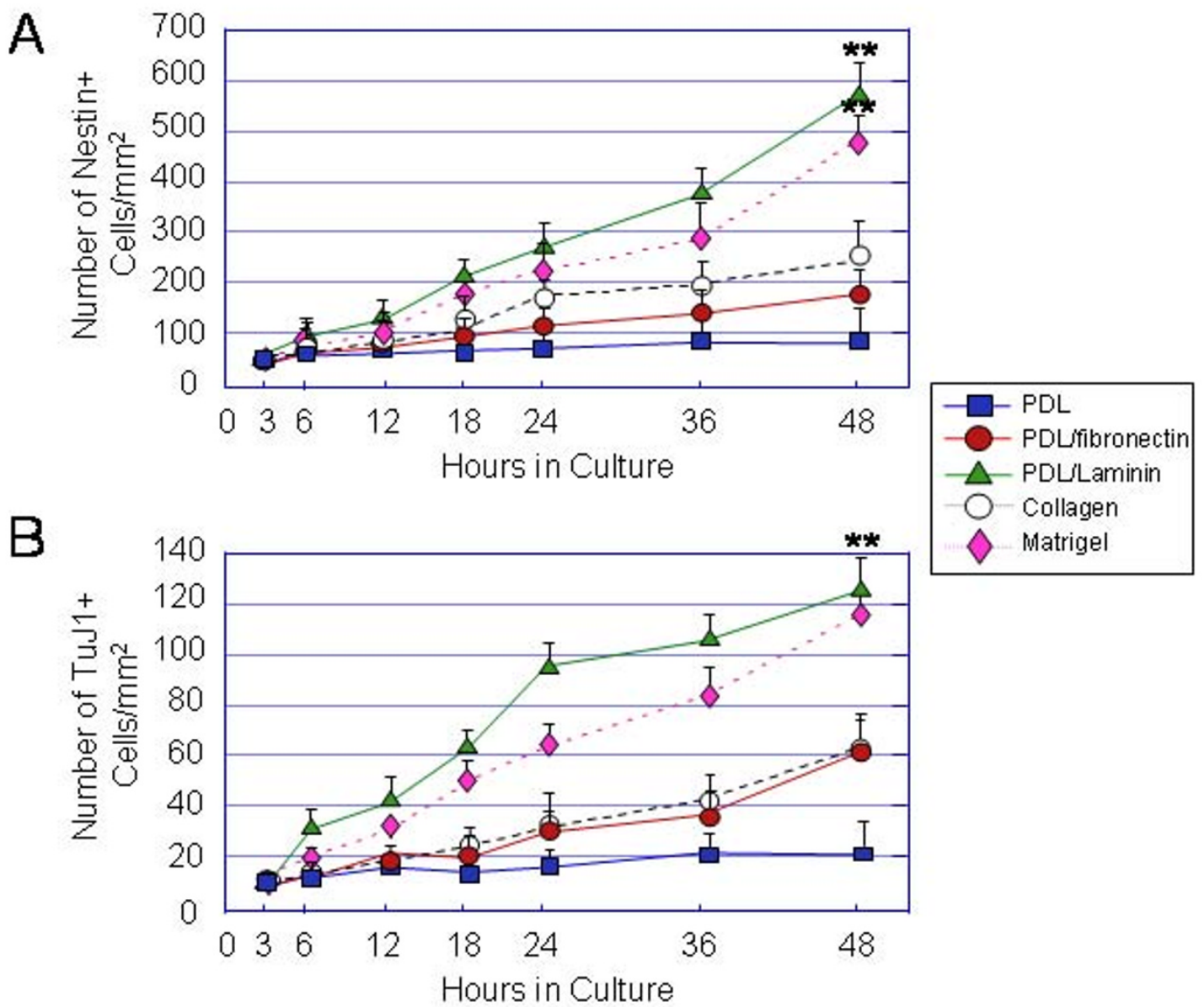

\section{Figure 7}

Expansion of hESC-derived nestin+ neural progenitors and $\mathrm{TuJ}+$ + neurons is greater on PDL/laminin and Matrigel substrates than on PDL, PDL/fibronectin and collagen substrates. (A) A linear plot summarizing the comparison of neural progenitor expansion on different substrates over time. Values are expressed in the number of nestin+ cells per surface area as mean \pm SEM of three independent experiments. The total number of cells per surface area is determined by counting DAPI labeled nuclei which overlapped phase-dark cells. Statistical differences for number of nestin+ cells $/ \mathrm{mm}{ }^{2}$ between laminin or Matrigel and PDL or fibrinectin or collagen at $48 \mathrm{~h}$ are significant $* * \mathrm{p}<0.0 \mathrm{I}$. (B) A linear plot summarizing the comparison of neuronal expansion on different substrates over time. Values are expressed in the number of TuJI+ cells per surface area as mean \pm SEM of three independent experiments. The total number of cells per surface area is determined by counting DAPI labeled nuclei which overlapped phase-dark cells. Statistical differences for number TuJ I+ cells $/ \mathrm{mm}^{2}$ between laminin or Matrigel and PDL or fibronectin or collagen at $48 \mathrm{~h}$ are significant $* * \mathrm{p}<0.0 \mathrm{I}$.

with PDL, fibronectin and type I collagen. Robust neuroectodermal precursors in neural rosettes were formed on laminin substrates and differentiated into greater numbers of neural progenitors and neurons with greater neurite outgrowth. We also found that laminin stimulated neural progenitor expansion and neurite outgrowth in a dose-dependent manner; the antibody against $\alpha 6$ or $\beta 1$ integrin subunit partially blocked the laminin-stimulated expansion of hESC-derived neural progenitors. These results indicate that the endogenous $\alpha 6$ and $\beta 1$ integrin subunits were in part responsible for transmitting laminin signaling into the cell to stimulate hESC-derived neural progenitor expansion and neuronal differentiation, suggesting that laminin/ $\alpha 6 \beta 1$ integrin signaling plays a significant role in the directed neural differentiation of hESCs.

The directed neural differentiation of hESCs in culture is a dynamic process which is essentially a recapitulation of early embryonic developmental processes [17]. Our 

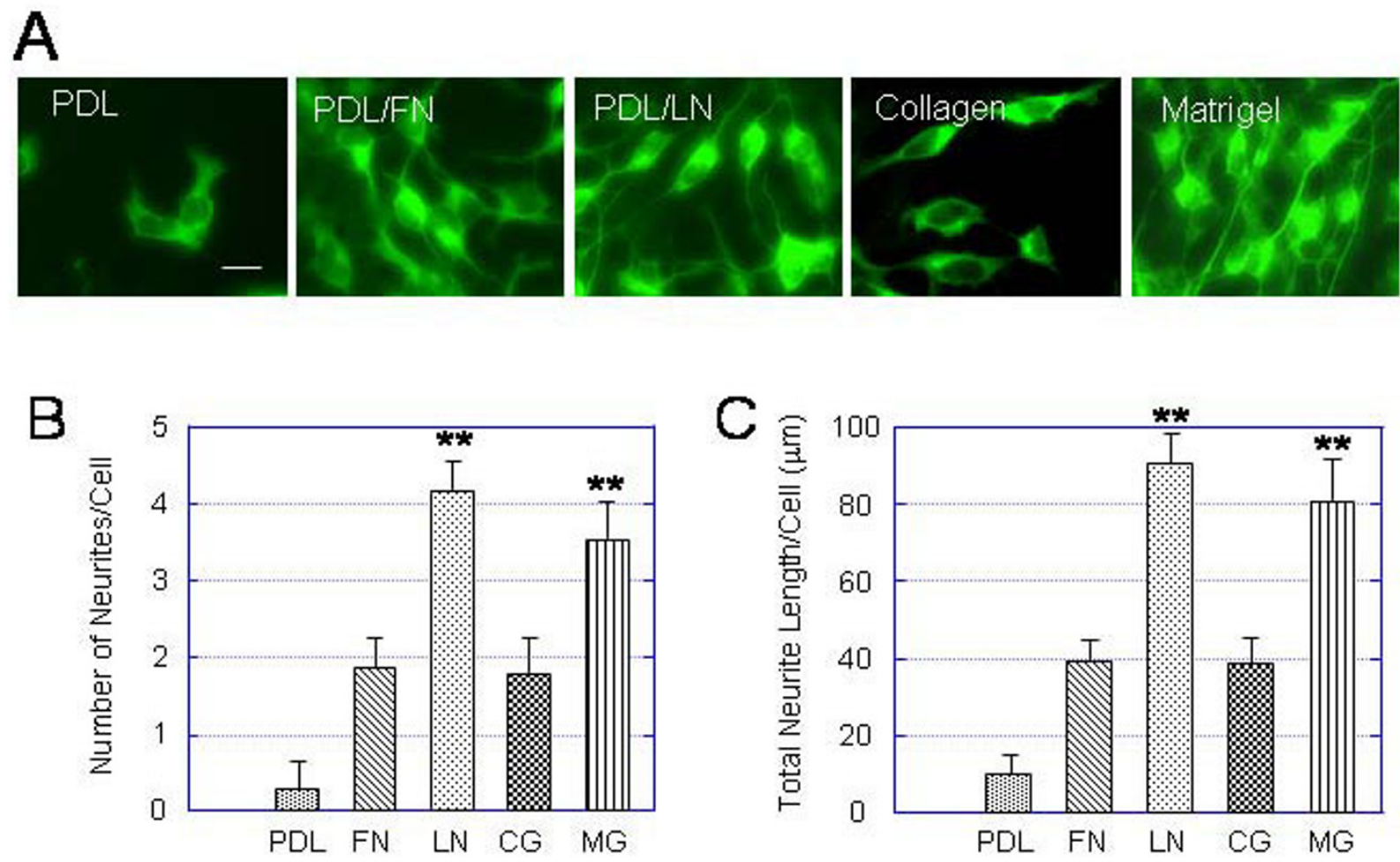

\section{Figure 8}

Neurite outgrowth of hESC-derived neurons are greater on PDL/laminin and matrigel substrates than other substrates. Light EBs were cultured on 5 different substrates: PDL, PDL/laminin, PDL/fibronectin, collagen and Matrigel for 3 days in the NDM and immunostained for TuJI. (A) A panel of immunofluorescent images showing representative fields of TuJI+ cells expanded on PDL, PDL/fibronectin (PDL/FN), PDL/laminin (PDL/LN), collagen and Matrigel for 3 days. (B, C) Bar plots summarizing the effect of different substrates on number of neuritis $(B)$ and total neurite length $(C)$ per cell. The laminin (LN)- and matrigel (MG)-induced number of neuritis and total neurite length per cell are significantly higher than on PDL, fibronectin (FN), and collagen (CG). Values are expressed as mean \pm SEM of 4 independent experiments. Statistical differences for number of neuritis and for total neurite length per cell between LM or MG and PDL or FN or CG are significant ** $P<$ 0.01 . Scale bar in $(A)=30 \mu \mathrm{m}$.

results from neural differentiation of hESCs in vitro are consistent with recent findings from in vivo studies. Evidence has shown that embryonic neural tissues contain a dynamic ECM, composed of many types of molecules that have distinct patterns of spatial and temporal expression. The laminin family is one of the most important ECM components within the neural stem cell niche. Neural stem cells derived from the mouse VZ, SVZ and the rostral migratory stream (RMS) to the olfactory bulb express high levels of integrin $\alpha 6 \beta 1$ and its ligand laminin $[10,18]$. Antibodies against the $\alpha 6$ or $\beta 1$ integrin subunits can disrupt neuroblast migration, suggesting an endogenous role for $\alpha 6 \beta 1$ integrin in guiding migration; laminin is a chemoattractant for neuroblasts of the SVZ/RMS, drawing neuroblasts away from their normal course of migration in a restricted fashion when injected as a tract of intact laminin, and in a dispersed fashion when provided as a more soluble peptide [18]. The latter studies emphasize a critical role of $\alpha 6 \beta 1$ integrin and its ligand, laminin, in controlling the direction of migrating neuroblasts in the adult CNS.

The responses of hESC-derived neural progenitors to ECM molecules found in the present study are similar to those of neural stem/precursor cells dissociated from human postnatal cortices [16] or from mouse ganglionic eminence [7]. In the latter studies, laminin matrices enhanced human neural stem cell migration, expansion and differentiation into neurons and astrocytes, and elongation of neurites from NSPC-derived neurons compared to poly-Lornithine and fibronectin. Ours and other studies indicate laminin interactions with $\alpha 6 \beta 1$ integrin represent one of the most important cell-ECM interactions as an early inductive signal to regulate neural stem and progenitor cell proliferation, migration and fate decision in vitro and within the embryonic mammalian brain. 

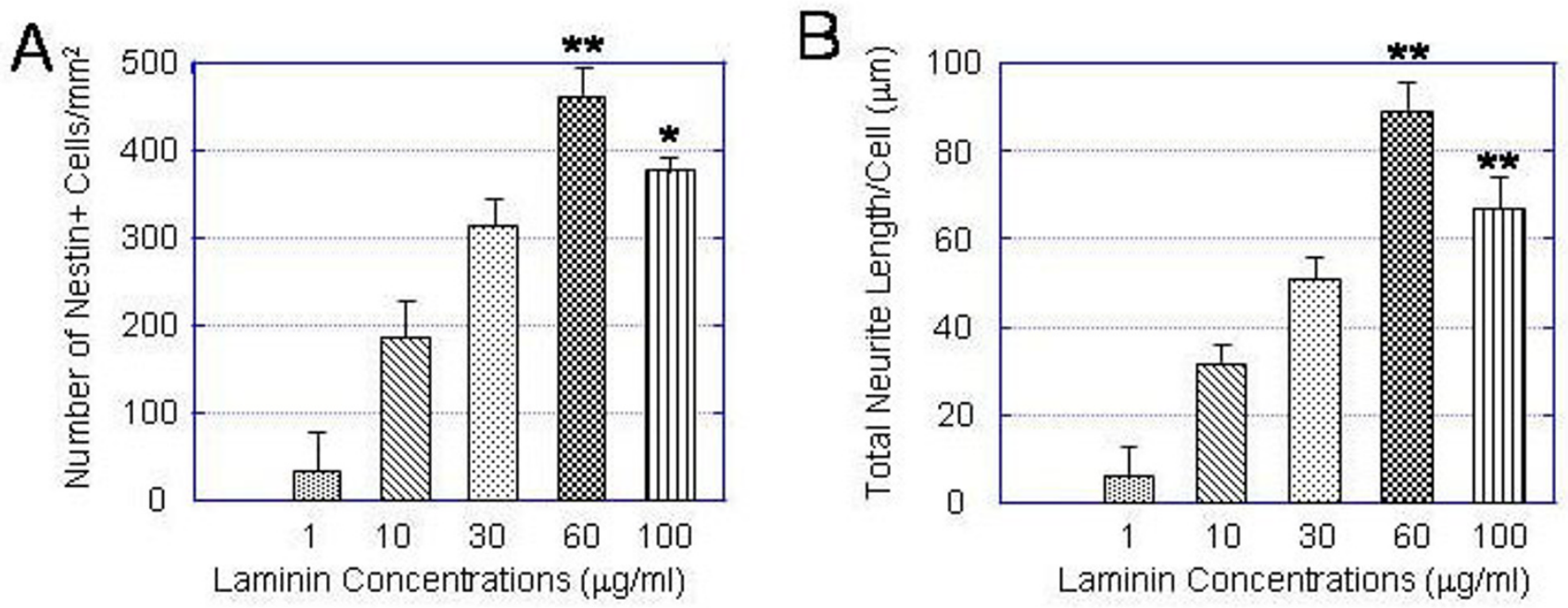

\section{Figure 9}

Laminin stimulates hESC-derived neural progenitor expansion and neuronal neurite outgrowth in a dosedependent manner. Dark EB-derived neural populations at 3 days postplating on PDL/laminin substrates with 5 different concentrations: I $\mu \mathrm{g} / \mathrm{ml}, 10 \mu \mathrm{g} / \mathrm{ml}, 30 \mu \mathrm{g} / \mathrm{ml}, 60 \mu \mathrm{g} / \mathrm{ml}$ and $100 \mu \mathrm{g} / \mathrm{ml}$. The cultures were double-immunostained for nestin and TuJ I. (A, B) Bar plots summarizing the responses of number of nestin+ neural progenitors (A) and total neurite length of TuJ I+ neurons (B) to different laminin concentrations. The neural progenitor expansion and total neurite length of neurons per cell increases with concentrations and reach a peak at $60 \mu \mathrm{g} / \mathrm{ml}$. Values are expressed as mean \pm SEM of 3 independent experiments. Statistical differences for cells $/ \mathrm{mm}^{2}$ and total neurite length per cell between $60 \mu \mathrm{g} / \mathrm{ml}$ or $100 \mu \mathrm{g} / \mathrm{ml}$ and I $\mu \mathrm{g} / \mathrm{ml}$ or 10 $\mu \mathrm{g} / \mathrm{ml}$ or $30 \mu \mathrm{g} / \mathrm{ml}$ are significant $* \mathrm{p}<0.05$; $* * \mathrm{p}<0.01$.

In the present study we focused on the involvement of the ECM components in the generation and migration of neural progenitors and neurite outgrowth of neurons during the neural specification of hESC. Laminin served as a potent stimulator of neural differentiation of hESCs while other tested ECM components showed similar but much less enhancement of these events. Recent evidence has increased our awareness of the diversity and complexity of the cell-matrix interactions. ECM components have both stimulatory and inhibitory effects on neural cell development [19], and much remains to be elucidated about how interactions with the ECM generate inductive signals that regulate the hESC differentiation in vivo and in vitro. On the other hand, cells in tissues encounter the composition of the ECM, rather than a single ECM protein. For example, the basement membrane and connective tissue contain networks of multiple ECM proteins including laminin, fibronectin and several collagen isoforms. Study of the role of combined ECM components, which regulate hESC-derived neural phenotypes, will greatly facilitate their use as model systems for neural development study and as therapeutic agents for cell replacement.

\section{Conclusion}

We demonstrated using a defined adherent culture system that neural derivation from hESCs was significantly enhanced by laminin or laminin-rich Matrigel compared to PDL, fibronectin and type I collagen substrates. Laminin stimulated neural progenitor generation, expansion and differentiation into neurons, as well as neurite outgrowth of hESC-derived neurons. The laminin-induced neural progenitor expansion was partially blocked by the antibody against $\alpha 6$ or $\beta 1$ integrin. These results implicate a possible role of laminin/ $\alpha 6 \beta 1$ integrin signaling in directed neural differentiation of hESCs. This finding is consistent with a significant role of laminin/integrin signaling in regulation of neural stem cell generation, migration and differentiation within the ventricular zone of CNS. Thus, cell-ECM interactions appear to be an early inductive signal to regulate neural specification of hESCs. Our findings may facilitate studies of early human CNS development and potential applications in neurological diseases.

\section{Methods}

In vitro maintenance and propagation of undifferentiated TE03 and TE06 hESCs

Human ESC lines TE03 (XX, passages P29 - P35) and TE06 (XY, approximately passage 35) were cultured according to the guidelines established by the National Academy of Sciences. Cells were propagated on a feeder layer of Mitomycin C. treated Mouse embryonic fibroblasts CF-1 (ATCC SCRC-1040.2; Manassas, VA; http:// www.atcc.org). Cells were cultured at $37^{\circ} \mathrm{C}, 5 \% \mathrm{CO}_{2}$ in ES 

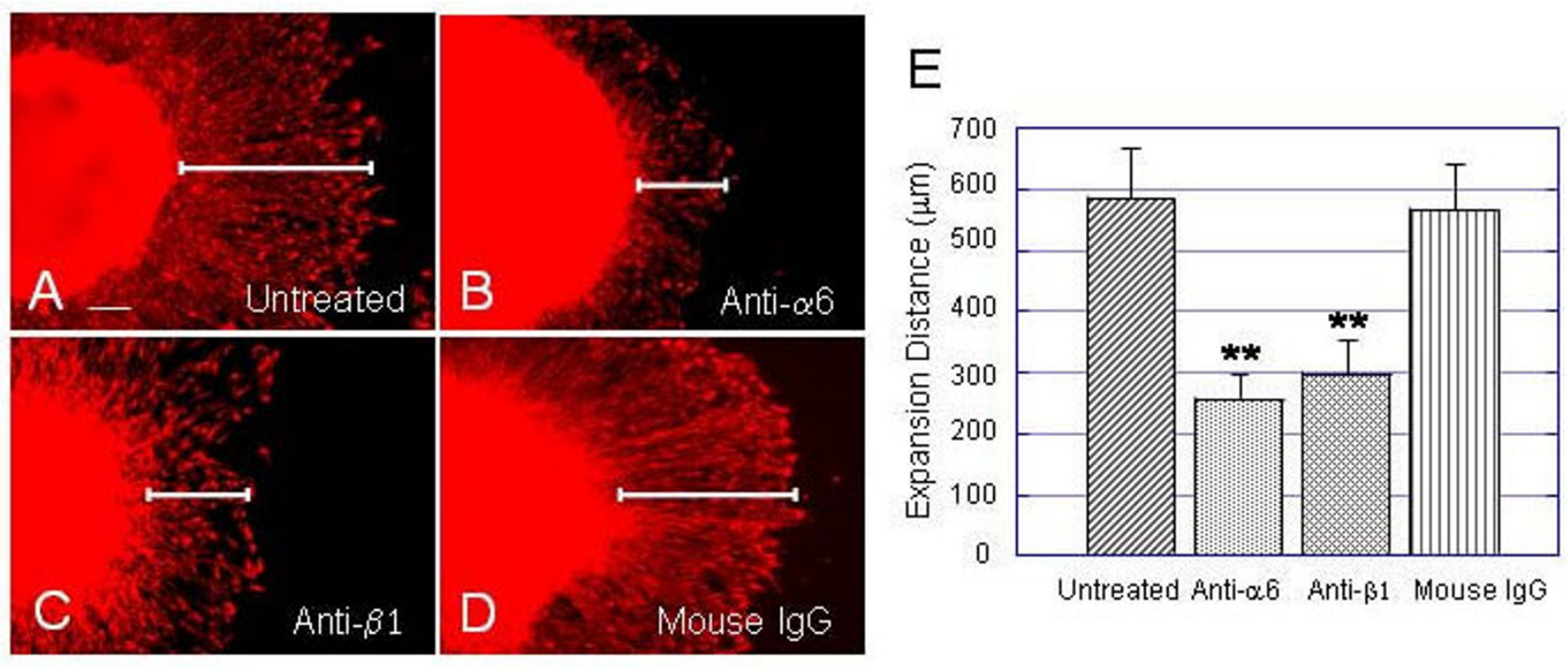

Figure 10

Anti- $\alpha 6$ or $\beta I$ integrin antibody blocks laminin-induced neural progenitor expansion. Antibody perturbation experiments were carried out in dark EB-derived neural populations at $24 \mathrm{~h}$ postplating on laminin substrate at $60 \mu \mathrm{g} / \mathrm{ml}$. A $10 \mu \mathrm{g} / \mathrm{ml}$ of antibody against $\alpha 6$ or $\beta I$ integrin, and a $10 \mu \mathrm{g} / \mathrm{ml}$ of purified mouse $\mathrm{IgG}$ were added into the culture medium directly at the beginning of cell culture. The expansion distance was determined by measuring the length from the edge of EB spheres to the widest point of the rim. (A-D) Immunofluorescent images of dark EB-derived neural populations show representative fields of nestin + cells treated with anti- $\alpha 6$ (B), anti- $\beta$ I (C), mouse lgG (D), and untreated (A). Inclusion of antibody against $\alpha 6$ or $\beta$ I significantly decreases cell expansion compared to untreated culture (A) and culture treated with mouse $\lg (\mathrm{D})$. The bar in (A) $=503 \mu \mathrm{m}$, in $(B)=23 \mathrm{I} \mu \mathrm{m}$, in $(C)=266 \mu \mathrm{m}$, and in $(D)=466 \mu \mathrm{m}$. (E) Bar plot summarizes the effects of various treatments on laminin-induced expansion distances. Values are expressed in expansion distance as mean \pm SEM of four independent experiments. Statistical differences for expansion distance between anti- $\alpha 6$ or $\beta I$ integrin treatment and untreated or treated with mouse lgG are significant: **p $<0.00 \mathrm{I}$. But the differences for expansion distance between mouse lgG treatment and untreated are not significant $p>0.05$. Scale bar in $(A)=100 \mu \mathrm{m}$.

medium-Dulbecco's modified Eagle's medium (D-MEM)/ F12 (ATCC 30-2006) (80\%), supplemented with $2.0 \mathrm{mM}$ L-Alanyl-L-Glutamine (ATCC 30-2115), $0.1 \mathrm{mM}$ Nonessential amino acids (ATCC 30-2116), $0.1 \mathrm{mM}$ 2-mercaptoethanol (Sigma Catalog No. M-7522; http:// www.sigmaaldrich.com) and $4 \mathrm{ng} / \mathrm{ml}$ basic fibroblast growth factor (bFGF) (R\& D Systems Catalog No. 233-FB) (5\%); Knockout serum replacement (Invitrogen Catalog No. 10828) (15\%); fetal bovine serum (ATCC SCRR-302020), Penicillin $(100 \mathrm{IU} / \mathrm{ml}) /$ streptomycin $(100 \mu \mathrm{g} / \mathrm{mL})$ (ATCC 30-2300). bFGF (4 ng/ml) was added in the first 24 hours after thawing the cells. Daily medium changes began after the first 48 hours in culture. Cells were passaged every 6 to 8 days using collagenase IV (200 Units/ $\mathrm{ml}$ ) (Invitrogen, Carlsbad, CA; http://www.invitro gen.com).

It has been a standard practice in our laboratory to monitor these cell lines by repeated sterility testing that ensures the cell cultures were free from mycoplasma, bacteria, fungi and viral pathogens.

\section{Spontaneous and directed neural differentiation and rosette formation}

The hES cell colonies were removed from MEF feeders and dissociated into small clumps by incubating with collagenase IV (200 Units/ml) (Invitrogen Carlsbad, CA; http:/ /www.invitrogen.com) at $37^{\circ} \mathrm{C}$ for 30 minutes. The hES cell clumps were pelleted and cultured in suspension in low attachment dishes with hES cell medium without bFGF for 5 days (the end of this stage is considered as at 5 days of differentiation). ES cells grew into floating aggregates or embryoid bodies (EBs), while remaining feeder cells adhered to the plate. The neuroectodermal induction began with EBs transferred into the neural differentiation medium (NDM) that consisted of modified Eagle's medium (ATCC 30-2002; http://www.atcc.org), F12k(ATCC 30-2004), N-2 supplement (Gibco Catalog No. 317740; http://www.invitrogen.com), $0.1 \mathrm{mM}$ Nonessential amino acids (ATCC 30-2116), Penicillin (100 $\mathrm{IU} / \mathrm{ml}) /$ streptomycin $(100 \mu \mathrm{g} / \mathrm{ml}$ ) (ATCC 30-2300) and 5 ng/ml bFGF (R\& D Systems Catalog No. 233-FB) for 10 days. At days 15-17 of differentiation, EBs were plated on 
substrate-coated $35 \mathrm{~mm}$ dishes. Although some neural rosettes were formed in floating EBs, increased rosettes were visualized after plating of the EBs on substrates. Neuroectodermal cells in neural rosettes further differentiated into neural progenitors and their progeny. Immunocytochemistry of neuroectodermal cells, neural progenitors and their progeny was carried out directly on substrates.

\section{Substratum preparations}

To examine ECM effects on neural differentiation of hESC in vitro, the treated polystyrene $35 \mathrm{~mm}$ cell culture dishes (Corning, NY; http://www.corning.com) were coated with the following substrates: Poly-D-Lysine (PDL), human placenta-derived fibronectin (FN), human placenta-derived laminin (LN), type I collagen and Matrigel. PDL, a positively-charged, synthetic molecule, was used to enhance cell attachment to plastic surfaces and enhance adsorption of ECM proteins to the culture substrate. In addition, we used human ESC Qualified Matrigel Matrix (BD Biosciences, Bedford, MA; http://www.bdbio sciences.com), a solubulized basement membrane preparation extracted from EHS mouse sarcoma (a tumor rich in ECM proteins); its major component is laminin (56\%), followed by collagen IV (31\%), heparan sulfate proteoglycans, and entactin (8\%). It provides a physiologically relevant environment for stimulation of cell proliferation and differentiation. Matrigel has been useful for studies of cell morphology, biochemical function, migration or invasion, and gene expression.

PDL (Sigma-Aldrich, St. Louis, MO; http://www.sig maaldrich.com) was reconstituted with sterile $\mathrm{ddH}_{2} \mathrm{O}$. The PDL solution was added to plates at $0.1-1 \mathrm{mg} / \mathrm{ml}$ and left overnight at room temperature. For laminin and fibronectin coating, dishes were pretreated with PDL as described above, fibronectin derived from human plasma (R \& D Systems, Minneapolis, MN; http://www.rndsystems.com) was added at $50 \mu \mathrm{g} / \mathrm{ml}$ in PBS, and laminin from human placenta (Sigma-Aldrich, St. Louis, MO; http://www.sig maaldrich.com) as added at $10-100 \mu \mathrm{g} / \mathrm{ml}$ in PBS. PDL, PDL/fibronectin, and PDL/laminin were left on dishes overnight in a humidified $37^{\circ} \mathrm{C}, 5 \% \mathrm{CO} 2$ incubator, and then the excess substrate was removed and dishes were rinsed with PBS.

To examine the effects of laminin concentrations on hESC-derived neurogenesis, we systematically measured neural progenitor expansion and total neurite length per neuron at 5 laminin coating concentrations: $1 \mu \mathrm{g} / \mathrm{ml}$ $\left(0.25 \mu \mathrm{g} / \mathrm{cm}^{2}\right), 10 \mu \mathrm{g} / \mathrm{ml}\left(2.5 \mu \mathrm{g} / \mathrm{cm}^{2}\right), 30 \mu \mathrm{g} / \mathrm{ml}(7.5 \mu \mathrm{g} /$ $\left.\mathrm{cm}^{2}\right), 60 \mu \mathrm{g} / \mathrm{ml}\left(15 \mu \mathrm{g} / \mathrm{cm}^{2}\right)$ and $100 \mu \mathrm{g} / \mathrm{ml}\left(25 \mu \mathrm{g} / \mathrm{cm}^{2}\right)$.

Collagen (Type I, Boehringer-Mannheim Corp., Indianapolis, IN; http://www.roche.com) purchased as a sterile, lyophilized powder, was dissolved to a final concentra- tion of $3 \mathrm{mg} / \mathrm{ml}$ by addition of sterile $0.2 \% \mathrm{v} / \mathrm{v}$ acetic acid ( $\mathrm{pH} 3-4)$. Then the collagen solution was diluted with an equal volume of $2 \times$ phosphate-buffered saline (PBS, Gibco; http://www.invitrogen.com) and a volume of cell media to achieve a final collagen concentration of $0.5 \mathrm{mg} /$ $\mathrm{ml}$ (maintaining physiological osmolarity, 250-300 mOsM). After adjusting the $\mathrm{pH}$ of the collagen solution to $\mathrm{pH} 7.4$ by the addition of $1 \mathrm{~N} \mathrm{NaOH}$, the solution was chilled in an ice bath to prevent gel formation. The collagen solution can be simply applied to $35 \mathrm{~mm}$ dishes or glass coverslips and allowed to dry.

Human ESC Qualified Matrigel Matrix was thawed overnight at $4^{\circ} \mathrm{C}$ then diluted 1:6 (approximately $16 \%$ Matrigel) in cold DMEM/F12 medium (ATCC, Manassas, VA; http://www.atcc.org). $35 \mathrm{~mm}$ cell culture dishes were coated on ice so as not to gel the Matrigel prematurely. The volumes of $16 \%$ Matrigel used to coat the tissue culture vessels were $1 \mathrm{ml}$ per $35 \mathrm{~mm}$ dish and $0.25 \mathrm{ml}$ per well in the 24 well plates. Culture dishes were kept on ice for 1 hour, and excess Matrigel was aspirated just prior to plating of neural progenitor cells.

\section{Immunocytochemistry}

To evaluate the neural differentiation potential of pluripotent hESCs, immunostaining for various neural markers was performed. The staining procedure was described previously [20]. Briefly, cultured cells were fixed for $15 \mathrm{~min}$ in $4 \%$ paraformaldehyde in PBS followed by incubation with the primary antibodies at $4{ }^{\circ} \mathrm{C}$ overnight. Appropriate secondary antibodies were added for single or double staining.

The following primary antibodies were used: rabbit antinestin (Millipore/Chemicon, Billerica, MA; http:// www.millipore.com; $1: 200)$, mouse Class $\operatorname{IgG}_{2 \mathrm{a}}$ anti- $\beta$ tubulin (TuJ1) (Millipore/Chemicon, Billerica, MA; http://www.millipore.com; 1:300), chicken polyclonal anti-Sox1 (Millipore/Chemicon, Billerica, MA; http:// www.millipore.com; 1:300), rabbit polyclonal antimusashi (Millipore/Chemicon, Billerica, MA http:// www.millipore.com; 1:300), mouse Class IgM anti-A2B5 (R\&D Systems, Minneapolis, MN; http://www.rndsys tems.com; 1:100), mouse Class IgM anti-PSA-NCAM (Millipore/Chemicon, Billerica, MA; http://www.milli pore.com; 1:300), mouse Class IgG1 anti-MAP2 a, b, c (Kamiya Biomedical company, Seattle, WA; http:// www.kamiyabiomedical.com; 1:100), rabbit glutamate decardoxylase (GAD) ${ }_{65 / 67}$ (Millipore/Chemicon, Billerica, MA, http://www.millipore.com; 1:200), mouse Class IgM clone 81 anti-O4 (Millipore/Chemicon, Billerica, MA; http://www.millipore.com; 1:100) and rabbit polyclonal anti-GFAP (Millipore/Chemicon, Billerica, MA http://www.millipore.com; 1:500). Secondary antibodies were FITC-conjugated donkey anti-mouse IgG $_{2 a}$ (South- 
ern Biotech, Birmingham, AL; http://www.southernbio tech.com; 1:50), rhodamine-conjugated donkey anti-rabbit IgG (Jackson ImmunoResearch, West Grove, PA; http://www.jacksonimmuno.com; 1:50), FITC-conjugated donkey anti-chicken IgG (Millipore/Chemicon, Billerica, MA, http://www.millipore.com; 1:50), FITCconjugated donkey anti-Mouse IgM (Jackson ImmunoResearch, West Grove, PA; http://www.jacksonim muno.com; 1:50) or AlexaFluor488 conjugated goat anti mouse IgG1 (Invitrogen/Molecular Probes, Eugene, OR; http://www.invitrogen.com; 1:50). Cell nuclei were labeled for $10 \mathrm{~min}$ with $0.8 \mu \mathrm{g} / \mathrm{ml} \mathrm{4,6-diamidino-2-phe-}$ nylindole (DAPI) (Sigma-Aldrich, St. Louis, MO; http:// www.sigmaaldrich.com).

To examine the distributions of integrins in hESC-derived neural progenitors, immunocytochemistry for lamininassociated integrins $\alpha 1, \alpha 3, \alpha 6, \beta 1$ and $\beta 4$ was performed in neural progenitors generated on PDL/laminin substrates. Antibodies against integrins $\alpha 1$ (clone MB1.2), $\alpha 3$ (clone ASC-6), $\alpha 6$ (clone NK1-GoH3), $\beta 1$ (clone HUTS$4)$ and $\beta 4$ (clone 3E1) were purchased from Chemicon (Millipore/Chemicon, Billerica, MA; http://www.milli pore.com; 1:100). Secondary antibody was FITC-conjugated donkey anti-Mouse IgG (Jackson ImmunoResearch, West Grove, PA; http://www.jacksonimmuno.com; 1:50). The distributions of immunofluorescent cells were examined under microscope (Nikon) eclipse TE 300 microscope with Bioimaging System.

\section{Double-immunocytochemistry for nestin and BrdU incorporation}

To examine the ability of hESC-derived neural progenitors (nestin+ cells) to synthesize DNA, bromodeoxyuridine (BrdU) incorporation with 5-bromo-2-deoxy-uridine labeling and Detection Kit I (Roche, Indianapolis, IN; http:/(www.roche.com) was used to monitor nestin+ cell proliferation. Cultures were exposed to $20 \mu \mathrm{M}$ BrdU for 4 hours and then fixed with $70 \%$ alcohol containing $50 \mathrm{mM}$ glycine at PH 2.0. After rinse, cells were incubated overnight with mouse anti-BrdU (1:1000) and rabbit anti-nestin (Millipore/Chemicon, Billerica, MA; http:// www.millipore.com; $1: 200)$, followed by incubation with a mixture of rhodamine-conjugated donkey anti-rabbit IgG and FITC-conjugated donkey anti-mouse IgG (Jackson Immunological Research, West Grove, PA) for 45 min. Some cultures not exposed to BrdU were used as negative controls and showed no immunoreactivity demonstrating the specificity of BrdU antibody. In the doublelabeling experiment, no cross-reactivity was detected between BrdU and anti-nestin antibodies. The distributions of double-immunostained nestin + and BrdU+ cells were examined and photographed with Nikon eclipse TE 300 microscope. A proliferation index was defined as the percentage of BrdU+ nuclei in the total number of cells evaluated. At least 500 labeled cells were counted from each dish.

\section{Antibody perturbation experiments}

To test the role of $\alpha 6$ or $\beta 1$ integrin in laminin-stimulated hESC-derived neural progenitor cell expansion, hESCderived dark EBs were plated on PDL/laminin substrates and cultured in the NDM. A $10 \mu \mathrm{g} / \mathrm{ml}$ of antibodies against $\alpha 6$ or $\beta 1$ integrin (Anti-Integrin alpha6, clone NKI-GoH3 from Chemicon; http://www.millipore.com; or Affinity purified anti-mouse integrin $\beta_{1}$ from eBioscience http://www.ebioscience.com) and a $10 \mu \mathrm{g} / \mathrm{ml}$ of purified mouse IgG (Chemicon) were added into the culture medium directly at the beginning of cell culture on a PDL/laminin substrate. Anti-integrin $\alpha 6$, clone NKI$\mathrm{GoH} 3$ is well characterized antibody which has been used to inhibit laminin binding $[21,22]$. Affinity purified antimouse integrin $\beta_{1}$ clone HMb1-1 has been reported to block VLA-dependent cellular functions, including the adhesion of mouse tumor cell lines to extracellular matrix proteins $[23,24]$. Compared to monoclonal anti-human integrin $\beta 1 / C D 29$ antibody clone P5D2 (R\&D systems, http://www.rndsystems.com) and anti- $\beta 1$ integrin antibody clone TASC/9D11, (Chemicon, http://www.milli pore.com), affinity purified anti-mouse integrin $\beta_{1}$ exhibited greater blocking effects, and was used for this study. Measurements of cell expansion were carried out in similar sized (diameter)-dark EB-derived neural populations at $24 \mathrm{~h}$ postplating.

\section{Quantification of hESC-derived neural cells and neurite outgrowth}

To quantify the percentage of hESC-differentiated neural progenitors and neurons, cell counting was performed from cultures double-immunostained for nestin and TuJ1, together with nuclear DAPI counterstaining, in 35 $\mathrm{mm}$ culture dishes coated with different ECM substrates from at least three independent experiments. Nestin+ and $\mathrm{TuJ} 1+$ cells were manually counted and were expressed as a percentage of the total differentiated cells. We found that DAPI stains both differentiated and undifferentiated cells, but differentiated cells usually exhibit phase-dark under microscope. Therefore, only those DAPI stained cells overlapped with phase-dark cells were counted as total differentiated cells. At least 2,000 total cells were evaluated per dish for one antigen expression. Two methods were used for cell expansion measurements. First, we counted the number of immunostained cells on different substrates from randomly selected fields. Second, we measured expansion distances in dark EBs-derived differentiation population in which the distance from the edge of the EB sphere to the widest point of the rim can be measured.

Neurite outgrowth was analyzed using the NIH image analysis software. Neurites were quantifies from images of 
neurons immunostained for TuJ1. Measurements of neurite outgrowth included the number of primary neurites per cell and total neurite length per cell. A neurite was defined as a process having longer than the width of one cell body terminating in a growth cone and neurites were recorded using trace function. The total number of neuritis and total neurite length were measured and divided by the number of cells observed in the field. The total neurite length per cell was calculated by averaging the sums of analysis. For these analyses, each captured image was identified as a sampling unit and data from three separate experiments were pooled. An average of 25 cells per image was analyzed in each experiment.

All data are expressed as mean \pm SEM, and Student's $t$ test was used for statistical evaluation. In all instances $* \mathrm{P}<$ 0.05 was considered statistically significant.

\section{Authors' contributions}

$\mathrm{WM}, \mathrm{MR}$ and MM were primarily responsible for the data analysis and writing and editing the manuscript. TT, ED and JS carried out the hES cell cultures and directed differentiation, and performed immunocytochemistry.

\section{Acknowledgements}

This work was supported by contract grant N0IAG40002 from NIH/ National Institute on Aging.

\section{References}

I. Schofield R: The relationship between the spleen colony-forming cell and the haemopoietic stem cell. Blood Cells 1978, 4:7-25.

2. Watt FM, Hogan BL: Out of Eden: stem cells and their niches. Science 2000, 287: 1427-I430.

3. Spradling A, Drummond-Barbosa D, Kai T: Stem cells and their niche. Nature 2001, 414:98-104.

4. Fuchs E, Tumbar T, Guasch G: Socializing with the neighbors: stem cells and their niche. Cell 2004, I I6:769-778.

5. Scadden DT: The stem-cell niche as an entity of action. Nature 2006, 44I: I075-1079.

6. Tanentzapf G, Devenport D, Godt D, Brown NH: Integrin-dependent anchoring of a stem-cell niche. Nat Cell Biol 2007, 9:14|3-14|8.

7. Tate MC, García AJ, Keselowsky BG, Schumm MA, Archer DR, LaPlaca MC: Specific beta I integrins mediate adhesion, migration, and differentiation of neural progenitors derived from the embryonic striatum. Mol Cell Neurosci 2004, 27:22-3I.

8. Hayashi $Y$, Furue MK, Okamoto T, Ohnuma K, Myoishi Y, Fukuhara $\mathrm{Y}$, Abe T, Sato JD, Hata R, Asashima M: Integrins regulate mouse embryonic stem cell self-renewal. Stem Cells 2007, 25:3005-30I5.

9. Letourneau PC, Condic ML, Snow DM: Interactions of developing neurons with the extracellular matrix. J Neurosci 1994, 14:915-928.

10. Lathia JD, Patton B, Eckley DM, Magnus T, Mughal MR, Sasaki T, Caldwell MA, Rao MS, Mattson MP, Ffrench-Constant C: Patterns of laminins and integrins in the embryonic ventricular zone of the CNS. I Comp Neurol 2007, 505:630-643.

II. Czyz J, Wobus A: Embryonic stem cell differentiation: the role of extracellular factors. Differentiation 200I, 68:167-174.

12. Goetz AK, Scheffler B, Chen HX, Wang S, Suslov O, Xiang H, Brüstle O, Roper SN, Steindler DA: Temporally restricted substrate interactions direct fate and specification of neural precursors derived from embryonic stem cells. Proc Natl Acad Sci USA 2006, 103:11063-11068.
13. Zhang SC, Wernig M, Duncan ID, Brüstle O, Thomson JA: In vitro differentiation of transplantable neural precursors from human embryonic stem cells. Nat Biotechnol 200 I, 1 9: I I 29-33.

14. Lazzari G, Colleoni S, Giannelli SG, Brunetti D, Colombo E, Lagutina I, Galli C, Broccoli V: Direct derivation of neural rosettes from cloned bovine blastocysts: a model of early neurulation events and neural crest specification in vitro. Stem Cells 2006, 24:25I4-252I.

15. Elkabetz Y, Panagiotakos G, Al Shamy G, Socci ND, Tabar V, Studer $L:$ Human ES cell-derived neural rosettes reveal a functionally distinct early neural stem cell stage. Genes Dev 2008, 22:152-165.

16. Flanagan LA, Rebaza LM, Derzic S, Schwartz PH, Monuki ES: Regulation of Human Neural Precursor cells by Laminin and Integrins. J. Neurosci Res 2006, 83:845-856.

17. Zhang SC: Neural subtype specification from embryonic stem cells. Brain Pathol 2006, 6: I32-142.

18. Emsley HG, Hagg T: $\alpha 6 \beta$ I integrin directs migration of neuronal precursors in adult mouse forebrain. Experimental Neurology 2003, I 83:273-285

19. Hynds DL, Snow DM: Fibronectin and laminin elicit differential behaviors from SH-SY5Y growth cones contacting inhibitory chondroitin sulfate proteoglycans. I Neurosci Res 200I, 66:630-642.

20. Ma W, Tavakoli T, Chen S, Maric D, Liu JL, O'Shaughnessy TJ, Barker JL: Reconstruction of functional cortical-like tissues from neural stem and progenitor cells. Tissue Eng Part A 2008, I4(10): 1673-86.

21. Chen MS, Almeida EAC, Huovila A-PJ, Takahashi Y, Shaw LM, Mercurio AM, White JM: Evidence that distinct States of the integrin a6ßI interact with laminin and an ADAM. I Cell Biol 1999, 144:549-56I.

22. Kikkawa $\mathrm{Y}$, Virtanen I, Miner JH: Mesangial cells organize the glomerular capillaries by adhering to the $\mathbf{G}$ domain of laminin alpha5 in the glomerular basement membrane. J. Cell Biol 2003, I6I:187-196.

23. Noto $\mathrm{K}$, Kato $\mathrm{K}$, Okumura $\mathrm{K}$, Yagita $\mathrm{H}$ : Identification and functional characterization of mouse CD29 with a mAb. Int Immunol 1995, 7:835-842.

24. Ridger VC, Wagner BE, Wallace WA, Hellewell PG: Differential effects of CD 18, CD29, and CD49 integrin subunit inhibition on neutrophil migration in pulmonary inflammation. J Immunol 200I, 166:3484-3490.
Publish with Bio Med Central and every scientist can read your work free of charge

"BioMed Central will be the most significant development for disseminating the results of biomedical research in our lifetime. "

Sir Paul Nurse, Cancer Research UK

Your research papers will be:

- available free of charge to the entire biomedical community

- peer reviewed and published immediately upon acceptance

- cited in PubMed and archived on PubMed Central

- yours - you keep the copyright
BiolMedcentral 